\title{
Methane flux of leaves in a tropical rainforest and a temperate conifer forest
}

\author{
Mai KAMAKURA* ${ }^{*}{ }^{\dagger}$, Yoshiko KosUGI**, Ryoji NAKAGAWA**, and Masayuki ITOH*** \\ $\left(\begin{array}{c}* \text { KYOUSEI Science Center for Life and Nature, Nara Women’s University, } \\ \text { Kita-uoya, Higashimachi, Nara, 630-8506, Japan } \\ * * \text { Laboratory of Forest Hydrology, Division of Environmental Science and Technology, } \\ \text { Graduate School of Agriculture, Kyoto University, Kyoto, 606-8502, Japan } \\ * * * \text { Center for Ecological Research, Kyoto University, 509-3, 2-chome, Hirano, Otsu, Shiga, 520-2113, Japan }\end{array}\right)$
}

\begin{abstract}
We measured methane $\left(\mathrm{CH}_{4}\right)$ fluxes of leaves growing in a tropical rainforest and a temperate conifer forest using the closed static chamber method. Leaf samples were chosen from the canopy and forest floor of a tropical rainforest at Pasoh Forest Reserve, Peninsular Malaysia and a temperate forest at Kiryu Experimental Watershed (KEW) , central Japan. At Pasoh, we sampled four species from the canopy (Xanthophyllum stipitatum, Dipterocarpus sublamellatus, Ptychopyxis caput-medusae, Neobalanocarpus heimii) and four species from the forest floor (Alphonsea maingayi, Rinorea anguifera, Macaranga lowii, Neobalanocarpus heimii). The leaves of Elaeis guineensis were also sampled at an oil palm plantation near the forest reserve area. At KEW, we sampled the leaves of Chamaecyparis obtusa, from both the top $(18 \mathrm{~m})$ and middle $(16 \mathrm{~m})$ of the canopy as well as leaves of Eurya japonica at the forest floor. Incubation experiments revealed that $\mathrm{CH}_{4}$ was emitted from leaves of the tested species sampled at two sites, although $\mathrm{CH}_{4}$ fluxes showed variations on a daily basis. These results suggest that tree leaves both at Pasoh and KEW might function as a small $\mathrm{CH}_{4}$ source, but their contribution to the $\mathrm{CH}_{4}$ exchange of the total forest ecosystem is very small compared to the soil $\mathrm{CH}_{4}$ flux.
\end{abstract}

Key words: Closed static chamber, Flux, Incubation, Leaf, Methane.

\section{Introduction}

Methane $\left(\mathrm{CH}_{4}\right)$ is the second most important greenhouse gas after $\mathrm{CO}_{2}$ (Forster et al., 2007), with a radiative potential 26 times more effective than $\mathrm{CO}_{2}$ (Lelieveld and Crutzen, 1992). Global anthropogenic sources of $\mathrm{CH}_{4}$ include fossil fuel-related industries, waste management, enteric fermentation, rice agriculture, and biomass burning and amount to $360 \mathrm{Tg}$ year $^{-1}$ (Le Mer and Roger, 2001). Concerning natural sources, wetlands emit up to $115 \mathrm{Tg}_{\mathrm{year}}{ }^{-1}$. Upland ecosystems are considered to be net sinks for $\mathrm{CH}_{4}$ with consumption by soils amounting to $30 \mathrm{Tg}_{\mathrm{year}}{ }^{-1}$. Oxidation by $\mathrm{OH}^{-}$radicals in the troposphere amounts to

Received; March 25, 2011.

Accepted; August 25, 2011.

†Corresponding Author: mkamakura@cc.nara-wu.ac.jp
$470 \mathrm{Tg}$ year ${ }^{-1}$. Global $\mathrm{CH}_{4}$ budgets estimate a missing source of about $10 \mathrm{Tg}$ year $^{-1}$, which might be explained by unexpected emissions from upland ecosystems or adjustments to any of the known $\mathrm{CH}_{4}$ sources and sinks (Megonigal and Guenther, 2008).

Based on incubation experiments under solar radiation, Keppler et al. (2006) reported that leaves of tree and grass species native to temperate and tropical regions emit $\mathrm{CH}_{4}$ under aerobic conditions, and extrapolations from laboratory measurements to the global scale indicated that $\mathrm{CH}_{4}$ emissions from plants could constitute a large fraction of the total global emissions of $\mathrm{CH}_{4}$ (amounting to about $149 \mathrm{Tg}_{\text {year }}{ }^{-1}$ ), although scaling the measurements up to global magnitude involves inherent uncertainty (Kirschbaum et al., 2006, 2007; Parsons et al., 2006; Butenhoff and Khalil, 2007). If large $\mathrm{CH}_{4}$ efflux from leaves as argued by Keppler et al. (2006) were true, $\mathrm{CH}_{4}$ emissions from 
plant leaves may have an important effect on global warming as a net source of $\mathrm{CH}_{4}$. Because Keppler et al. (2008) suggest the methoxyl group of plant pectin as a precursor of aerobic $\mathrm{CH}_{4}$ in which production from the pectin component of plant cell walls can be evoked by ultraviolet (UV) radiation, Vigano et al. (2008) showed that $\mathrm{CH}_{4}$ emissions from dry and detached fresh matter of temperate and tropical plants can be stimulated by UV radiation and/or heating.

In addition to temperate and tropical plant species, Kitaoka et al. (2007) observed $\mathrm{CH}_{4}$ emissions from fresh leaves of typical tree species native to cooltemperate forests in Hokkaido in northern Japan using incubation experiments with a PPFD of $350 \mu \mathrm{mol} \mathrm{m}$ $\mathrm{s}^{-1}$. Wang et al. (2008) conducted laboratory incubation experiments using detached leaves and stems of hydrophytes and xerophytes indigenous to the temperate Inner Mongolia Steppe. They found that some herbaceous hydrophytes emitted $\mathrm{CH}_{4}$ from stems, but not from detached leaves; also, some xerophytes emitted $\mathrm{CH}_{4}$ from detached leaves but not from stems. However, using a highly accurate, traceable online analytical system, no evidence for substantial aerobic $\mathrm{CH}_{4}$ emissions from photosynthesizing and dark-respiring leaves of $\mathrm{C}_{3}$ (Nicotiana tabacum L.) and $\mathrm{C}_{4}$ (Zea mays L.) grass species was provided by Beerling et al. (2008). Dueck et al. (2007) also reported no detectable ${ }^{13} \mathrm{CH}_{4}$ emissions from either $\mathrm{C}_{3}$ or $\mathrm{C}_{4}$ grasses labeled with the heavy stable isotope carbon ${ }^{13} \mathrm{C}$ to allow detection of subsequent $\mathrm{CH}_{4}$ emissions that are isotopically distinct from background values using highly sensitive photoacoustic spectroscopy. Therefore, the issue of $\mathrm{CH}_{4}$ emissions from plants remains open from the perspective of various data on $\mathrm{CH}_{4}$ fluxes using different approaches, and the physiological mechanisms responsible for $\mathrm{CH}_{4}$ emission under aerobic conditions are unclear. Evaluating whether $\mathrm{CH}_{4}$ emissions from plants affect $\mathrm{CH}_{4}$ exchange between the forest ecosystem and the atmosphere is important.

The objective of this study was to describe whether $\mathrm{CH}_{4}$ fluxes of detached fresh tree leaves growing in a tropical rainforest and a temperate forest watershed have impacts on total $\mathrm{CH}_{4}$ flux in each forest ecosystem. Methane flux in tropical forests greatly impacts global climate. Tropical forests are the habitat for termites that are known to produce $\mathrm{CH}_{4}$ (Zimmerman et al., 1982; Frankenberg et al., 2005), whereas tropical forest soils almost always consume $\mathrm{CH}_{4}$ (Keller et al.,
1986). In temperate forest watersheds, wetlands reportedly function as large sources of $\mathrm{CH}_{4}$ (Itoh et al., 2007). We investigated $\mathrm{CH}_{4}$ fluxes of detached fresh leaves using incubation experiments and then compared the results to those of other studies conducted under different experimental conditions and soil $\mathrm{CH}_{4}$ fluxes, which represents an active area of $\mathrm{CH}_{4}$ flux research.

\section{Materials and Methods}

\subsection{Site and materials}

The study was conducted at the Pasoh Forest Reserve of the Forest Research Institute Malaysia (FRIM), near Simpang Pertang in Negeri Sembilan, Peninsular Malaysia $\left(2^{\circ} 58^{\prime} \mathrm{N}, 102^{\circ} 18^{\prime} \mathrm{E}\right)$ and the Kiryu Experimental Watershed (KEW; 34 $58^{\circ} \mathrm{N}$, $\left.136^{\circ} 00^{\prime} \mathrm{E}\right)$ in the southeast of Shiga Prefecture, central Japan.

The core area is composed of primary forest $(600$ ha) in the Pasoh Forest reserve (2450 ha) and is covered with a primary lowland mixed dipterocarp forest (tropical evergreen broadleaf forest), consisting of various species of Shorea and Dipterocarpus. The continuous canopy height is about $35 \mathrm{~m}$, although some emergent trees exceed $45 \mathrm{~m}$. The soil A horizon is thin $(0-5 \mathrm{~cm})$ and lateritic gravels are abundant below $30 \mathrm{~cm}$ (Yamashita et al., 2003). This forest has two rainy periods that occur from March to May and from October to December, although monthly rainfall shows considerable interannual fluctuations (about $200 \mathrm{~mm}$ month $^{-1}$, Kosugi et al., 2008). The annual mean air temperature during 2002-2007 measured at the top of the tower $(52 \mathrm{~m})$ was $25.5^{\circ} \mathrm{C}$, and the annual mean rainfall measured with a tipping bucket rain gauge at an observatory located $430 \mathrm{~m}$ from the tower was $1754 \mathrm{~mm}$. The oil palm plantation near the forest reserve area was also selected as a study site because different dominant (forest, oil palm, or sago ecosystem) underlying environmental factors in tropical peatland affect the exchange of $\mathrm{CH}_{4}$ between ecosystems and the atmosphere (Melling et al., 2005). At Pasoh, we sampled leaves of four tree species from the canopy [Xanthophyllum stipitatum Benn., Dipterocarpus sublamellatus Foxw., Ptychopyxis caput-medusae (Hk.f.) Ridl., Neobalanocarpus heimii (King) Ashton] and four tree species from the forest floor [Alphonsea maingayi Hook. f. et Th., Rinorea anguifera O. Ktze., Macaranga lowii King ex Hook f., Neobalano- 
carpus heimii (King) Ashton.] three times in the rainy season (December 11, 2007 and October 13-14, 2008). Canopy trees were accessible from a triangle canopy corridor $31 \mathrm{~m}$ high. The leaves of Elaeis guineensis Jacq. vat. dura Beet. were also sampled at the oil palm plantation near the forest reserve area four times in the dry and rainy seasons (on June 9-10, 2008 and October 14-15, 2008, respectively). According to Keppler et al. (2006) and Kitaoka et al. (2007), irradiation may affect $\mathrm{CH}_{4}$ emission from leaves. To examine the effect of solar radiation on $\mathrm{CH}_{4}$ flux of leaves, leaf sampling was conducted both at dawn $(07: 00-08: 30)$ and in the late afternoon (15:00-16:00). Three branches of each species were cut and immediately soaked in distilled water.

KEW (5.99 ha) is about $99.3 \%$ covered by the evergreen conifer Japanese cypress (Chamaecyparis obtusa Sieb. et Zucc.), which was planted in 1959 (average height: $13.9 \mathrm{~m}$, maximum height: $21.1 \mathrm{~m}$ ), and $0.67 \%$ covered by distinct wetland in riparian zones. The soil texture is sandy or sandy silt (Itoh et al., 2009). The annual mean air temperature and rainfall during 2008, measured at an open site observatory, was $13.0^{\circ} \mathrm{C}$ and $1635 \mathrm{~mm}$, respectively. At KEW, we sampled leaves of C. obtusa from both the top (18 m) and middle $(16 \mathrm{~m})$ canopy and collected leaves of Eurya japonica Thunb. at the forest floor five to eleven times during the period from May 2008 to January 2009. Three branches of both species were cut and soaked in distilled water in the late afternoon (around 15:00-16:00).

\subsection{Methane flux measurements}

The $\mathrm{CH}_{4}$ fluxes of leaves were measured using the closed static chamber method. In the laboratory, leaves from three samples were detached and put in glass vial chambers $(50,100 \mathrm{ml})$, sealed with a silicon septum or PVC-chambers (330, 450, $670 \mathrm{ml}$ ) and incubated in the dark for $16 \mathrm{~h}$ at $30^{\circ} \mathrm{C}$. To avoid the effect of pressure change on $\mathrm{CH}_{4}$ concentration in the chamber, $\mathrm{CH}_{4}$ flux measurements were conducted only before and after incubation. At KEW, $0.5-2.0 \mathrm{ml}$ of air in the chamber was collected with a gastight syringe, then the $\mathrm{CH}_{4}$ concentration was measured with a gas chromatograph (GC; GC-14BPF; Shimadzu, Kyoto, Japan) equipped with a flame ionization detector (FID) and a Porapak Q column $(2 \mathrm{~m} \times 3 \mathrm{~mm}$ diameter; Shinwa Chemical Industries, Kyoto, Japan) using $\mathrm{N}_{2}$ (flow rate, $50 \mathrm{ml} \mathrm{min}^{-1}$ ) as the carrier gas. At Pasoh, 5 or 10 $\mathrm{ml}$ of air in the chamber was collected in a vacuum glass vial, and $\mathrm{CH}_{4}$ flux measurements using a GC were conducted in the laboratory at Kyoto, Japan. Blank samples were also measured with the GC. Measurements of $\mathrm{CH}_{4}$ concentration were conducted within 10 days after air sampling at Pasoh and within $24 \mathrm{~h}$ at KEW. After GC analysis, leaf area was measured using a portable area meter (LI3000-A, Li-Cor Inc., Lincoln, Nebraska, USA). Dry weights of leaves were obtained after drying at $40^{\circ} \mathrm{C}$ for a minimum of $48 \mathrm{~h}$. Methane flux of leaves per unit leaf area $\left(\phi_{\mathrm{LA}}\right.$, ng $\mathrm{cm}^{-2} \mathrm{~h}^{-1}$ ) was calculated from the linear regressions of the concentration versus time curves from the chambers as follows:

$$
\phi_{L A}=\frac{\rho V}{A} \frac{d c}{d t}
$$

where $A$ is the leaf area $\left(\mathrm{cm}^{2}\right), \rho$ is air density in the chamber $\left(\mathrm{ng} \mathrm{cm}^{-3}\right), V$ is the chamber volume $\left(\mathrm{cm}^{3}\right)$, and $d c / d t$ is the linear change in gas concentration within the chamber $\left(\mathrm{mol} \mathrm{mol}{ }^{-1} \mathrm{~h}^{-1}\right)$. The air density was adjusted for the air temperature measured at the time of sampling. Similarly, $\mathrm{CH}_{4}$ flux of leaves per unit leaf dry weight $\left(\phi_{d w}\right.$, ng $\left.g_{d w}{ }^{-1} h^{-1}\right)$ was calculated as follows:

$$
\phi_{d w}=\frac{\rho V}{D W} \frac{d c}{d t}
$$

where $D W$ is the dry weight of leaves $\left(\mathrm{g}_{\mathrm{dw}}\right)$. Positive fluxes indicate emission of gas from the leaf to the atmosphere; negative fluxes indicate net absorption of gas from the atmosphere by the leaf.

\subsection{Statistical analysis}

Tukey tests were used to determine any differences among the means of $\mathrm{CH}_{4}$ flux of leaves for the different sampling dates $(p<0.05)$.

\section{Results}

\subsection{Methane fluxes of tree leaves at Pasoh (tropical rainforest)}

At Pasoh, 0.25 $\pm 0.21 \mathrm{ng} \mathrm{CH}_{4} \mathrm{gdw}^{-1} \mathrm{~h}^{-1}$ was emitted from leaves of canopy tree species (mean $\pm \mathrm{SD}$; Fig. 1a). Small $\mathrm{CH}_{4}$ absorption was observed from leaves of $X$. stipitatum and D. sublamellatus sampled at dawn in October $2008(-0.07 \pm 0.09$ and $-0.13 \pm 0.12 \mathrm{ng}$ $\mathrm{CH}_{4} \mathrm{~g}_{\mathrm{dw}}{ }^{-1} \mathrm{~h}^{-1}$, respectively), although no clear temporal variation of $\mathrm{CH}_{4}$ fluxes was detected from leaves of the other two species. The $\mathrm{CH}_{4}$ fluxes of A. mainga- 
(a)

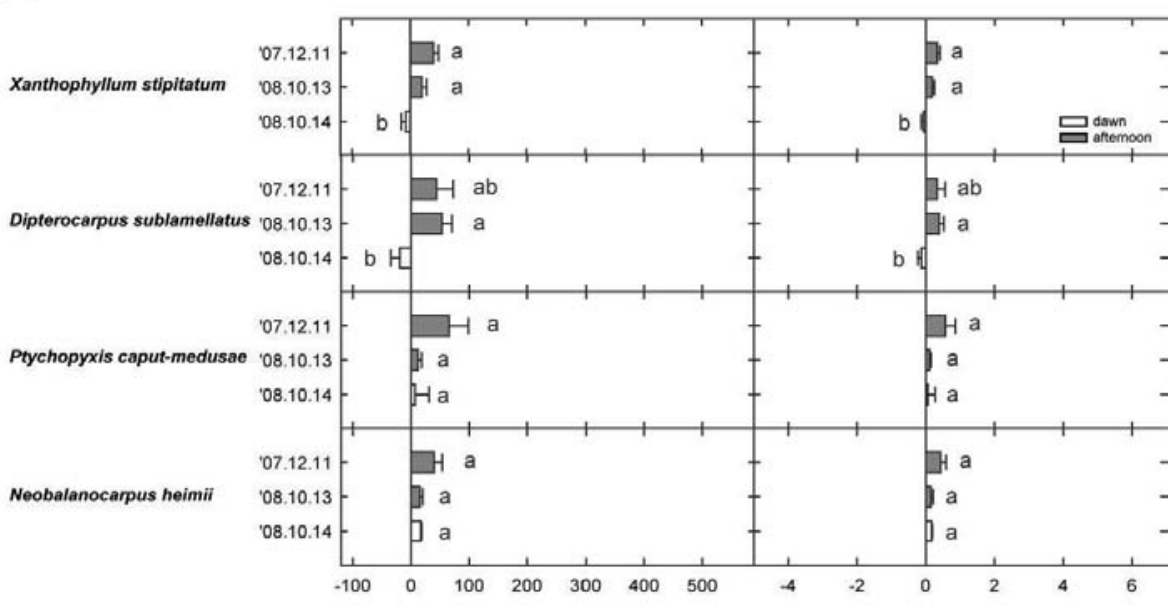

(b)
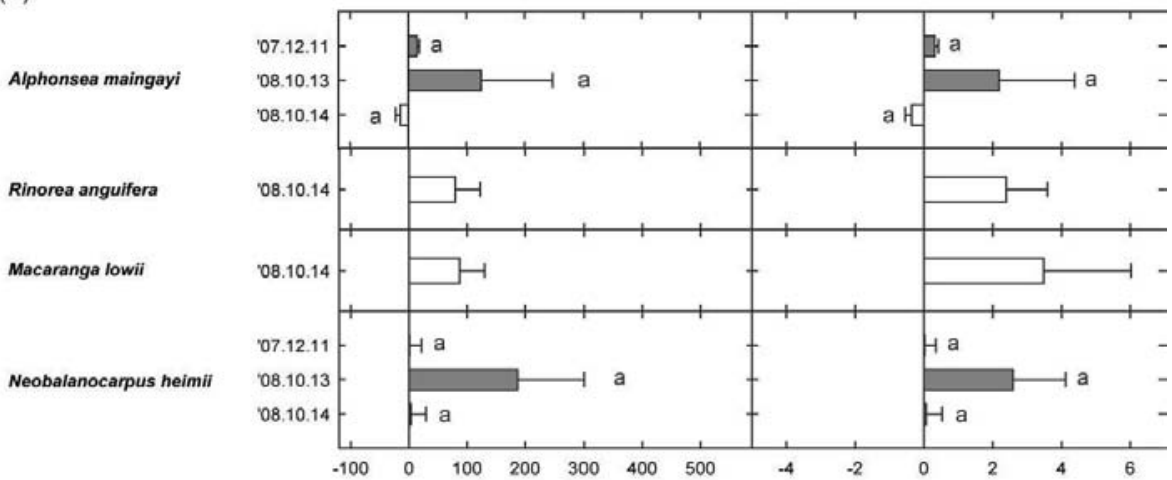

(c)

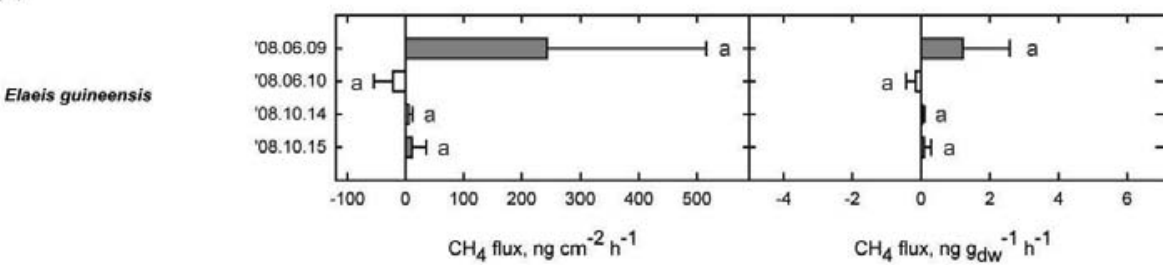

Fig. 1. Methane fluxes of tree leaves sampled from the canopy (a), forest floor (b), and oil palm plantation (c) at Pasoh. Methane fluxes were standardized per unit leaf area (ng $\mathrm{cm}^{-2} \mathrm{~h}^{-1}$, left side) and per unit leaf dry weight (ng $g_{d w}{ }^{-1} h^{-1}$, right side). Within each graph, the bars labeled with lower-case letters differ significantly [Tukey test: $p<0.05$ ].

$y i$ and $N$. heimii at the forest floor varied on daily basis, with mean rates ranging from -0.36 to 2.18 and from 0.01 to $2.59 \mathrm{ng} \mathrm{CH}_{4} \mathrm{~g}_{\mathrm{dw}}{ }^{-1} \mathrm{~h}^{-1}$, respectively, but no significant difference was observed between sampling dates (Fig. 1b). The leaves of E. guineensis also showed day-to-day variations in $\mathrm{CH}_{4}$ fluxes, with mean rates ranging from -0.17 to $1.22 \mathrm{ng} \mathrm{CH}_{4} \mathrm{~g}_{\mathrm{dw}}{ }^{-1} \mathrm{~h}^{-1}$, but no significant difference was detected (Fig. 1c). Methane fluxes of leaves from each tree species were several orders of magnitude smaller than those from unsaturated soil (Fig. 3a). 1.55 $2.62 \mathrm{mg} \mathrm{CH}_{4} \mathrm{~m}^{-2}$ day $^{-1}$ was emitted and $0.98 \pm 0.72 \mathrm{mg} \mathrm{CH}_{4} \mathrm{~m}^{-2}$ day $^{-1}$ 
(a)

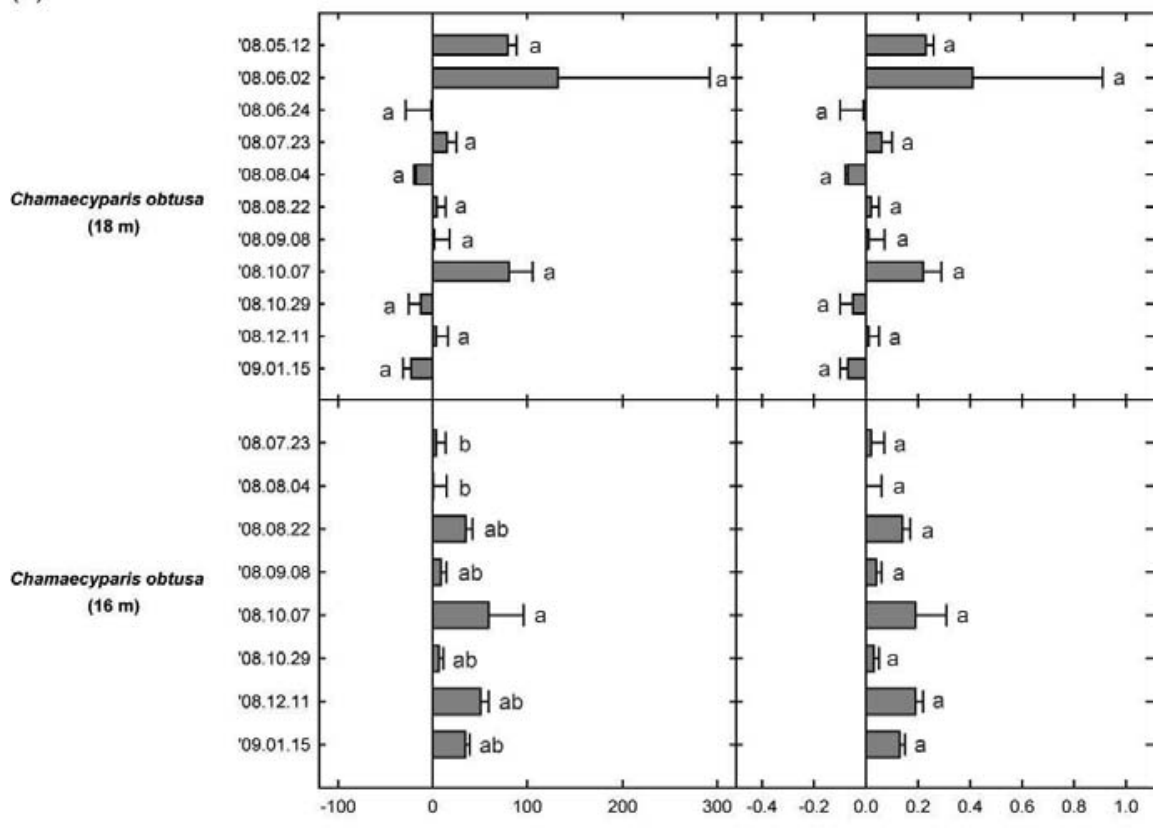

(b)

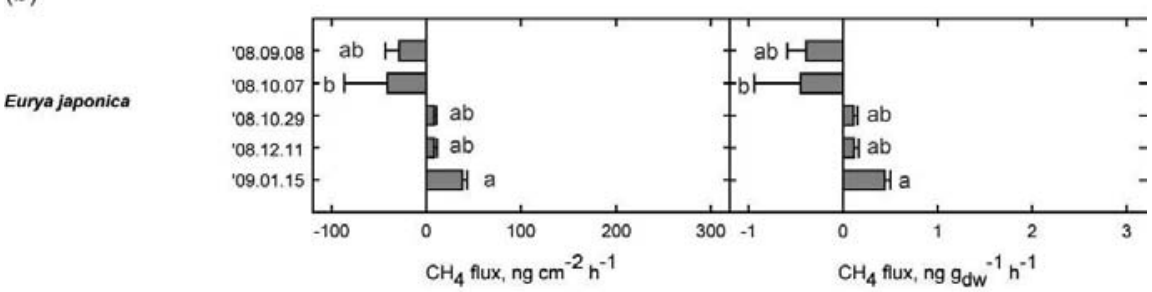

Fig. 2. Methane fluxes of Chamaecyparis obtusa leaves sampled from the top (18 m) and middle (16 m) of the canopy (a), and Eurya japonica leaves sampled from the forest floor (b) at KEW. Methane fluxes were standardized per unit leaf area (ng $\mathrm{cm}^{-2} \mathrm{~h}^{-1}$, left side) and per unit leaf dry weight $\left(\mathrm{ng} \mathrm{g}_{\mathrm{dw}}{ }^{-1} \mathrm{~h}^{-1}\right.$, right side). Within each graph, the bars labeled with lower-case letters differ significantly [Tukey test: $p<0.05$ ].

was absorbed in unsaturated soil, whereas $(7 \pm 10) \times 10^{-7} \mathrm{mg} \mathrm{CH}_{4} \mathrm{~m}^{-2}$ day $^{-1}$ was emitted and $(4 \pm 6) \times 10^{-7} \mathrm{mg} \mathrm{CH}_{4} \mathrm{~m}^{-2}$ day $^{-1}$ was absorbed in tree leaves.

\subsection{Methane fluxes of tree leaves at KEW (tem- perate forest)}

At KEW, both emission and absorption of $\mathrm{CH}_{4}$ from C. obtusa leaves at the top of the canopy (18 m) were observed, with mean rates ranging from -0.07 to 0.41 ng $\mathrm{CH}_{4} \mathrm{~g}_{\mathrm{dw}}{ }^{-1} \mathrm{~h}^{-1}$, but no seasonal change of $\mathrm{CH}_{4}$ fluxes was detected (Fig. 2a). Methane emissions per unit leaf area from $C$. obtusa leaves at the middle of the canopy (16 m) were significantly larger on October 7 , 2008 (59.10 $\left.\pm 45.32 \mathrm{ng} \mathrm{CH}_{4} \mathrm{~cm}^{-2} \mathrm{~h}^{-1}\right)$. However, a clear difference in $\mathrm{CH}_{4}$ emissions per unit leaf dry weight was not observed between sampling dates, with mean rates ranging from 0 to $0.19 \mathrm{ng} \mathrm{CH}_{4} \mathrm{~g}_{\mathrm{dw}}{ }^{-1} \mathrm{~h}^{-1}$. In E. japonica leaves from the forest floor, $\mathrm{CH}_{4}$ absorption on October 7, $2008\left(-0.45 \mathrm{ng} \mathrm{CH}_{4} \mathrm{~g}_{\mathrm{dw}}{ }^{-1} \mathrm{~h}^{-1}\right)$ and $\mathrm{CH}_{4}$ emission on January 15, 2009 (0.44 ng $\mathrm{CH}_{4} \mathrm{~g}_{\mathrm{dw}}{ }^{-1}$ $\mathrm{h}^{-1}$ ) were prominent (Fig. 2b). Methane fluxes of leaves from $C$. obtusa and E. japonica were several orders of magnitude smaller than those from both wetlands and unsaturated soil (Fig. 3b). 44.05 \pm 139.68 $\mathrm{mg} \mathrm{CH}_{4} \mathrm{~m}^{-2}$ day $^{-1}$ was emitted and $0.35 \pm 0.23 \mathrm{mg} \mathrm{CH}_{4}$ $\mathrm{m}^{-2}$ day $^{-1}$ was absorbed in soil, whereas $(8 \pm 11) \times 10^{-7}$ $\mathrm{mg} \mathrm{CH}_{4} \mathrm{~m}^{-2}$ day $^{-1}$ was emitted and $(4 \pm 6) \times 10^{-7} \mathrm{mg}$ $\mathrm{CH}_{4} \mathrm{~m}^{-2}$ day ${ }^{-1}$ was absorbed in tree leaves. 
(a)

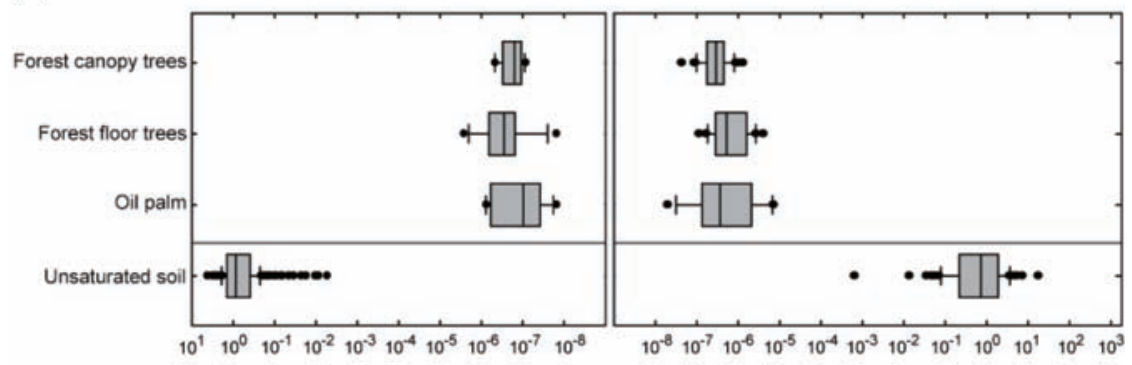

(b)

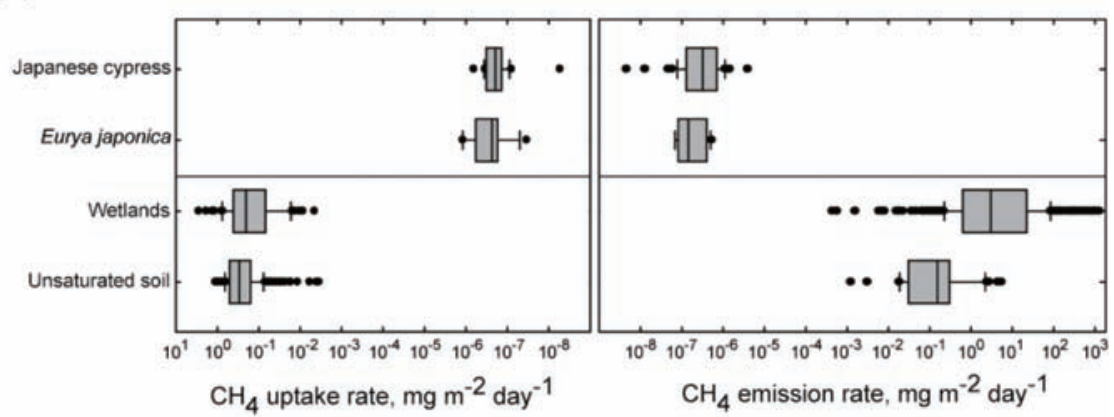

Fig. 3. Comparison of $\mathrm{CH}_{4}$ fluxes of tree leaves with soil $\mathrm{CH}_{4}$ fluxes at Pasoh (a) and KEW (b). Using leaf area index (LAI), $\mathrm{CH}_{4}$ fluxes from tree leaves were standardized per unit plot area $\left(\mathrm{mg} \mathrm{m}^{-2}\right.$ day $\left.^{-1}\right)$. The box plots show the median, interquartile range, and extreme cases of individual variables. Soil $\mathrm{CH}_{4}$ flux data at Pasoh were from Itoh (unpublished data), which were measured at five points in the 2-ha plot near the a triangle canopy corridor. Soil $\mathrm{CH}_{4}$ flux data at KEW were from Itoh et al. $(2007,2009)$, which were measured at nine points in both wetlands and unsaturated soil plots. 


\section{Discussion}

In this study, small $\mathrm{CH}_{4}$ emissions from leaves were found for each of the representative tree species at Pasoh and KEW (Figs. 1 and 2). The averaged $\mathrm{CH}_{4}$ fluxes from leaves of each species showed day-to-day variations, but no temporal and seasonal trends were detected. These results suggest that environmental factors such as solar radiation and air temperature did not affect $\mathrm{CH}_{4}$ fluxes from leaves. The range of values in $\mathrm{CH}_{4}$ fluxes per unit leaf dry weight observed in this study was much smaller compared to some recent incubation experiments (Table 1) and was within the fluctuation range of $\mathrm{CH}_{4}$ fluxes, which was not significantly different from zero when measured with a highaccuracy, traceable online analytical system (Beerling et al., 2008). These findings suggest that tree leaves growing at Pasoh and KEW may have the potential to emit and in some cases absorb $\mathrm{CH}_{4}$, but the mechanism is unknown and the amount is not significant. In both sites, $\mathrm{CH}_{4}$ fluxes from tree leaves were several orders of magnitude smaller than those from the soil (Fig. 3). Although studies have reported that soil $\mathrm{CH}_{4}$ fluxes at Pasoh and KEW are significant (Itoh et al., 2009, Itoh, unpublished data), the contribution of $\mathrm{CH}_{4}$ fluxes from foliage to the $\mathrm{CH}_{4}$ exchange of the total forest ecosystem at both sites is far smaller than that from soil.

Note that the amount of $\mathrm{CH}_{4}$ emission from plant leaves reported recently is highly variable among measurement conditions (Table 1). Comparing $\mathrm{CH}_{4}$ emission rates from leaves among studies, longtime incubation (up to $72 \mathrm{~h}$ ), high temperature $\left(35-40^{\circ} \mathrm{C}\right.$ ), and UV irradiation induce remarkable $\mathrm{CH}_{4}$ emissions (Kitaoka et al., 2007; Vigano et al., 2008). Vigano et al. (2008) and Keppler et al. (2008) reported that temperature and UV mediate the formation of $\mathrm{CH}_{4}$, which is produced from fresh and dry organic matter, as well as several structural plant components. If UV is an important factor for $\mathrm{CH}_{4}$ release from plants, then $\mathrm{CH}_{4}$ emissions may be suppressed in the absence of

Table 1. Comparison of methane emission rates of plants.

\begin{tabular}{|c|c|c|c|}
\hline Plants & $\begin{array}{c}\text { Methane } \\
\text { emission rates, } \\
\mathrm{ng} \mathrm{CH}_{4} \mathrm{dw}^{-1} \mathrm{~h}^{-1} \\
\end{array}$ & Experimental conditions & References \\
\hline $\mathrm{C}_{3}$-leaf 'temperate regions' & $0.19-21.6^{*}$ & Incubation experiments with solar & \multirow{5}{*}{$\begin{array}{l}\text { Keppler } \\
\text { et al. } \\
(2006)\end{array}$} \\
\hline $\mathrm{C}_{3}$-leaf ‘tropical regions’ & $0.09-17^{*}$ & radiation & \\
\hline $\mathrm{C}_{4}$-leaf & $0.21-10.1^{*}$ & (for $16 \mathrm{~h}$ at 30 or $40^{\circ} \mathrm{C}$ ) & \\
\hline $\mathrm{C}_{3}$-intact plant & $12-873 *$ & \multirow[t]{2}{*}{ Chamber experiments } & \\
\hline $\mathrm{C}_{4}$-intact plant & $55-762$ & & \\
\hline $\mathrm{C}_{3}$-leaf ‘cool-temperate regions’ & $9.1-31.3$ & $\begin{array}{l}\text { Incubation experiments with PPFD } \\
\text { of about } 350 \mu \mathrm{mol} \mathrm{m} \mathrm{m}^{-2} \mathrm{~s}^{-1} \text { (for up } \\
\text { to } 72 \mathrm{~h} \text { at } 35^{\circ} \mathrm{C} \text { ) }\end{array}$ & $\begin{array}{l}\text { Kitaoka } \\
\text { et al. } \\
(2007)\end{array}$ \\
\hline $\mathrm{C}_{3}$-'hydrophyte’ & $6.78-13.50^{*}$ & \multirow{3}{*}{$\begin{array}{l}\text { Incubation experiments } \\
\left(\text { for } 10-20 \mathrm{~h} \text { at } 20-22^{\circ} \mathrm{C}\right)\end{array}$} & \multirow{3}{*}{$\begin{array}{c}\text { Wang } \\
\text { et al. } \\
\text { (2008) } \\
\end{array}$} \\
\hline $\mathrm{C}_{3}$-'xerophyte’ & $0.55-3.39 *$ & & \\
\hline $\mathrm{C}_{4}{ }^{-}$'xerophyte' & $0.48 *$ & & \\
\hline $\begin{array}{l}\text { leaves of terrestrial plants } \\
\text { (including moss, grass, and trees) }\end{array}$ & $0-4300$ & $\begin{array}{l}\text { Incubation experiments with UV } \\
\text { radiation (at } 20-40^{\circ} \mathrm{C} \text { ) }\end{array}$ & $\begin{array}{c}\text { Vigano } \\
\text { et al. (2008) }\end{array}$ \\
\hline $\mathrm{C}_{3}$-leaf (Tobacco) & n. d. & \multirow{2}{*}{$\begin{array}{l}\text { A high-accuracy traceable online } \\
\text { analysis with photosynthetically } \\
\text { active radiation }\end{array}$} & \multirow{2}{*}{$\begin{array}{l}\text { Beerling } \\
\text { et al. } \\
\text { (2008) }\end{array}$} \\
\hline $\mathrm{C}_{4}$-leaf (Mays) & n. d. & & \\
\hline $\begin{array}{l}\mathrm{C}_{3} \text {-leaf 'crops' (grown under different } \\
\text { temperature, } \mathrm{CO}_{2} \text { concentration and } \\
\text { watering regime) } \\
\end{array}$ & $85.6-115.5$ & $\begin{array}{l}\text { Incubation experiments } \\
\text { (for } 2 \mathrm{~h} \text { at } \sim 22^{\circ} \mathrm{C} \text { ) }\end{array}$ & $\begin{array}{c}\text { Qaderi } \\
\text { and Reid } \\
(2011) \\
\end{array}$ \\
\hline leaves of tropical trees & $-0.55-6.02$ & \multirow{2}{*}{$\begin{array}{l}\text { Incubation experiments } \\
\text { (for } 16 \mathrm{~h} \text { at } 30^{\circ} \mathrm{C} \text { ) }\end{array}$} & \multirow[t]{2}{*}{ This study } \\
\hline leaves of temperate trees & $-0.94-0.91$ & & \\
\hline
\end{tabular}

* including the data that no $\mathrm{CH}_{4}$ emission was detected or was too weak to quantify change in $\mathrm{CH}_{4}$ concentration. 
UV wavelengths, as confirmed by Dueck et al. (2007) and Beerling et al. (2008). Also, irradiation treatment during incubation has also been suggested to enhance $\mathrm{CH}_{4}$ emission from leaves (Keppler et al., 2006; Kitaoka et al., 2007), but a significant difference in $\mathrm{CH}_{4}$ fluxes between leaves sampled in the afternoon and those sampled at dawn was observed in only two tree species at Pasoh. Thus, the effect of solar radiation on $\mathrm{CH}_{4}$ fluxes from leaves of plants under natural conditions may not be as large as previously reported. A possibility exists of aerobic $\mathrm{CH}_{4}$ release from plants via a biophysical rather than an enzymatic process (Kirschbaum et al., 2006).

To estimate the impact of $\mathrm{CH}_{4}$ fluxes of plants on its exchange between the forest ecosystem and atmosphere, the most important factor is whether plants can be a net $\mathrm{CH}_{4}$ source under field conditions. Although some studies have estimated total $\mathrm{CH}_{4}$ emissions from terrestrial plant communities (Megonigal et al., 2004; Keppler et al., 2006; Kirschbaum et al., 2006), large variations in $\mathrm{CH}_{4}$ fluxes from plant leaves caused by different measurement conditions will result in serious errors in estimating total $\mathrm{CH}_{4}$ fluxes from terrestrial plant communities under aerobic conditions. Some studies indicate that tree leaves in a floodplain forest can transport $\mathrm{CH}_{4}$ from an anaerobic root zone to the atmosphere through woody tree parts (Terazawa et al., 2007; Qaderi and Reid, 2011). In such tree species, gases such as ethylene $\left(\mathrm{C}_{2} \mathrm{H}_{4}\right)$ and $\mathrm{CH}_{4}$ can move from roots to shoots either via the transpiration stream or through aerenchyma, which slowly develop as a result of flooding. If plants do not have a known biochemical pathway to synthesize $\mathrm{CH}_{4}$ but rather take up this gas produced by microbial activities under aerobic conditions, the growing conditions of plants will largely affect $\mathrm{CH}_{4}$ emission from terrestrial parts. To evaluate whether the forest canopy is a net $\mathrm{CH}_{4}$ source, the monitoring of diurnal and seasonal changes in $\mathrm{CH}_{4}$ fluxes from living plants under field conditions is urgent.

\section{Acknowledgments}

This research was partially supported by the Japan Society for the Promotion Science (JSPS), Grant-inAim for Scientific Research.

\section{References}

Beerling, D. J., Gardiner, T., Leggett, G., Mcleod, A., and Quick, W. P., 2008: Missing methane emissions from leaves of terrestrial plants. Global Change Biol., 14, 1821-1826.

Butenhoff, C. L., and Khalil, M. A. K., 2007: Global methane emissions from terrestrial plants. Environ. Sci. Technol., 41, 4032-4037.

Dueck, T. A., de Visser, R., Poorter, H., Persijn, S., Gorissen, A., de Visser, W., Schapendonk, A., Verhagen, J., Snel, J., Harren, F. J. M., Ngai, A. K. Y., Verstappen, F., Bouwmeester, H., Voesenek, L. A. C. J., and van der Werf, A., 2007: No evidence for substantial aerobic methane emission by terrestrial plants: a ${ }^{13}$ C-labelling approach. New Phytol., 175, 29-35.

Forster, P., Ramaswamy, V., Artaxo, V., Berntsen, T., Betts, R., Fahey, D. W., Haywood, J., Lean, J., Lowe, D. C., Myhre, G., Naganga, J., Prinn, R., Raga, G., Schulz, M., and Dorland, R. V., 2007: Changes in atmospheric constituents and in radiative forcing. In Climate Change 2007: The Physical Science Basis. Contribution of Working Group I to the Fourth Assessment report of the Intergovernmental Panel on Climate Change (ed. by Solomon, S., Qin, D., Manning, M., Chen, Z., Marquis, M., Averyt, K. B., Tignor, M., and Miller, H. L.). Cambridge University Press, Cambridge, UK and New York, pp. 129-234.

Frankenberg, C., Meirink, J. F., vanWeele, M., Platt, U., and Wagner, T., 2005: Assessing methane emissions from global space-borne observations. Science, 308, 1010-1014.

Itoh, M., Ohte, N., Koba, K., Katsuyama, M., Hayamizu, K., and Tani, M., 2007: Hydrologic effects on methane dynamics in riparian wetlands in a temperate forest catchment. J. Geophys. Res., 112, G01019, doi:10.1029/2006JG000240.

Itoh, M., Ohte, N., and Koba, K., 2009: Methane flux characteristics in forest soils under an East Asian monsoon climate. Soil Biol. Biochem., 41, 388-395.

Keller, M., Kaplan, W. A., and Wofsy, S. C., 1986: Emissions of $\mathrm{N}_{2} \mathrm{O}, \mathrm{CH}_{4}$, and $\mathrm{CO}_{2}$ from tropical forest soils. J. Geophys. Res., 91, 11791-11802.

Keppler, F., Hamilton, J. T. G., Braß, M., and Röckmann, T., 2006: Methane emissions from terrestrial plants under aerobic conditions. Nature, 439, 187191.

Keppler, F., Hamilton, J. T. G., McRoberts, W. C., Vigano, I., Braß, M., and Röckmann, T., 2008: Methoxyl groups of plant pectin as a precursor of 
atmospheric methane: evidence from deuterium labeling studies. New Phytol., 178, 808-814.

Kirschbaum, M. U. F., Bruhn, D., Etheridge, D. M., Evans, J. R., Farquhar, G. D., Gifford, R. M., Paul, K. I., and Winters, A. J., 2006: A comment on the quantitative significance of aerobic methane release by plants. Funct. Plant Biol., 33, 521-530.

Kirschbaum, M. U. F., Niinemets, U., Bruhn, D., and Winters, A .J., 2007: How important is aerobic methane release by plants? Funct. Plant Sci. Biotechnol., 1, 138-145.

Kitaoka, S., Sakata, T., Koike, T., Tobita, H., Uemura, A., Kitao, M., Maruyama, Y., Sasa, K., and Utsugi, H., 2007: Methane emission from leaves of larch, birch and oak saplings grown at elevated CO2 concentration in northern Japan - Preliminary study-. J. Agric. Meteorol., 63, 201-206.

Kosugi, Y., Takanashi, S., Ohkubo, S., Matsuo, N., Tani, M., Mitani, T., Tsutsumi, D., and Abdul Rahim, N., 2008: $\mathrm{CO}_{2}$ exchange of a tropical rainforest at Pasoh in Peninsular Malaysia. Agric. For. Meteorol., 148, 439-452.

Lelieveld, J., and Crutzen, P. J., 1992: Indirect chemical effects of methane on climate warming. Nature, 355, 339-342.

Le Mer, J., and Roger, P., 2001: Production, oxidation, emission and consumption of methane by soils: a review. Eur. J. Soil Biol., 37, 25-50.

Megonigal, J. P., and Guenther, A. B., 2008: Methane emissions from upland forest soils and vegetation. Tree Physiol., 28, 491-498.

Megonigal, J. P., Hines, M. E., and Visscher, P. T., 2004: Anaerobic metabolism: linkages to trace gasses and aerobic processes. In Biogeochemistry (ed. by Schlesinger, W. H.) . Elsevier-Pergamon, Oxford, pp. 317-424.
Melling, L., Hatano, R., and Goh, K. J., 2005: Methane fluxes from three ecosystems in tropical peatland of Sarawak, Malaysia. Soil Biol. Biochem., 37, 14451453.

Parsons, A. J., Newton, P. C. D., Clark, H., and Klliher, F. M., 2006: Scaling methane emissions from vegetation. Trends Ecol. Evol., 21, 423-424.

Qaderi, M. M., and Reid, D. M., 2011: Stressed crops emit more methane despite the mitigating effects of elevated carbon dioxide. Funct. Plant Biol., 38, 97105.

Terazawa, K., Ishizuka, S., Sakata, T., Yamada, K., and Takahashi, M., 2007: Methane emissions from stems of Fraxinus mandshurica var. japonica trees in a floodplain forest. Soil Biol. Biochem., 39, 26892692.

Vigano, I., van Weelden, H., Holzinger, R., Keppler, F., McLeod, A., and Röckmann, T., 2008: Effect of UV radiation and temperature on the emission of methane from plant biomass and structural components. Biogeosciences, 5, 937-947.

Wang, Z. -P., Han, X. -G., Wang, G. G., Song, Y., and Gulledge, J., 2008: Aerobic methane emission from plants in the Inner Mongolia Steppe. Environ. Sci. Technol., 42, 62-68.

Yamashita, T., Kasuya, N., Kadir, W. R., Chik, S. W., Seng, Q. E., and Okuda, T., 2003: Soil and belowground characteristics of Pasoh Forest Reserve. In Pasoh: Ecology of a lowland rain forest in southeast Asia (ed. by Okuda, T., Manokaran, N., Matsumoto, Y., Niilima, K., Thomas, S. C., and Ashton, P. S.) . Springer-Verlag, Tokyo, pp. 89-109.

Zimmerman, P. R., Greenberg, J. P., Wandiga, S. O., and Crutzen, P., 1982: Termites: a potentially large source of atmospheric methane, carbon dioxide, and molecular hydrogen. Science, 218, 563-565. 